JBEE: JOURNAL BUSINESS, ECONOMIC AND ENTREPRENEURSHIP

https://journal.shantibhuana.ac.id/index.php/bee/index

JBEE Volume 3 No 12021

\title{
PERAN WANITA PETANI MEMBANGUN EKONOMI RUMAH TANGGA DALAM MENGENTASKAN KEMISKINAN DI DUSUN PEDALAMAN 3T
}

\author{
Deffrinica \\ Institut Shanti Bhuana Bengkayang, Kalimantan Barat, Indonesia \\ deffrinica@shantibhuana.ac.id
}

\begin{abstract}
Abstrak
Secara umum wanita yang bekerja tidak hanya untuk menghabiskan waktu luang mereka atau mengembangkan kemampuan yang mereka miliki tetapi karena adanya permasalahan ekonomi yang mengharuskan adanya peran wanita dalam meningkatkan pendapatan rumah tangga. Tujuan dari penelitian ini adalah untuk mengetahui peran wanita dalam membangun ekonomi rumah tangga petani dalam mengentaskan kemiskinan di Dusun Jirak Desa Karya Bhakti Kecamatan Sungai Betung Kabupaten Bengkayang Kalimantan Barat. Metode Kualitatif digunakan oleh peneliti dalam memberikan penjelasan tentang fakta-fakta. Hasil penelitian menunjukkan bahwa peran wanita petani sebagai istri atau ibu rumah petani dalam meningkatkan ekonomi rumah tangga petani relatif penting dan kuat karena proses pengambilan keputusan yang berkaitan dengan kebutuhan ekonomi dan sosial bagi keluarga didominasi oleh para wanita. Sehingga peran wanita petani sebagai ibu rumah tangga di dusun jirak pedalaman di Daerah Kabupaten Bengkayang sangat berpengaruh dalam memenuhi kebutuhan rumah tangga berupa kebutuhan hidup seharihari, kebutuhan anak sekolah dan kebutuhan untuk kesehatan.
\end{abstract}

Kata kunci: Ekonomi, Kemiskinan, Wanita Petani, FGD. 


\section{PENDAHULUAN}

\section{Latar Belakang}

Pada dasarnya pembangunan terus di lakukan demi mencapai tujuan masyarakat yang adil dan makmur, namun proses pembangunan ini terganggu ketika krisis moneter tahun 1997 melanda Indonesia dan pada era tersebut semakin terlihat jelas jurang antara golongan miskin dan golongan kaya. Badan Pusat Statistik mendefinisikan golongan penduduk miskin adalah golongan masyarakat yang memiliki pemenuhan kebutuhan minimum per orang per hari sebesar 2100 kalori atau sama dengan pendapatan perkapita per bulan untuk daerah perdesaan. Untuk masalah kemiskinan di Indonesia menggunakantiga penggolongan, yaitu masyarakat yang hidup di bawah garis kemiskinan, masyarakat yang hidup tepat di batas garis kemiskinan, dan yang terakhir adalah golongan masyarakat yang hidup di atas batas garis kemiskinan.

Perubahan susunan sosial ini terutama banyak di rasakan bagi kaum wanita, karena pada abad sebelumnya kaum wanita banyak mengalami penindasan dan pemerkosaan atas hak kemerdekaannya. Kaum laki-laki tidak mengakui kemerdekaan bagi kaum perempuan, dengan demikian kehidupan kaum wanita diliputi kegelapan dalam hidupnya. Sejak timbulnya revolusi masyarakat, terutama dalam Revolusi Perancis dan kekuasaan yang baru dari golongan masyarakat mengakibatkan adanya sifat berlomba-lomba, saling menghalangi, disebabkan oleh hasrat berjuang untuk memperoleh kemerdekaannya.

Dengan adanya perubahan berarti menggerakan kebudayaan, yakni dalam dinamika perkembangan bidang sosial ekonomi, yang menyebabkan perubahan suatu penyusunan baru dalam dinamika perkembangannya bidang sosial ekonomi, yang menyebabkan perubahan suatu penyusunan baru dalam perimbangan kekuasaan. Baik pria dan wanita tidak ada garis pemisah dalam kehidupan dan negara, tetapi sama-sama berhak untuk menentukan kemajuannya. Potensi wanita yang kian hari kian penting arti dan perannya perlu diusahakan peningkatnnya, bahwasanya di dalam Undang-undang Dasar Republik Indonesia Tahun 1945, tidak ada kalimat yang mengandung perbedaan antara laki-laki dan wanita, antara lain terdapat dalam pasal: 26, 27, 30, dan 30. Usaha meningkatkan peranan dan sumbangan wanita dalam pembangunan, termaksud menunjang perekonomian keluarga, ternyata wanita Indonesia menyadari sepenuhnya meningkatkan taraf hidup dan kemajuan, sehingga terpenuhi kebutuhan spritual dan materil. Potensi wanita yang cukup besar jumlahnya mempunyai arti dan mengambil bagian secara aktif baik dalam pembangunan dan meningkatkan perekonomian keluarga.

Memasuki era globalisasi dan semakin meningkatnya kesadaran dan pemerataan kesempatan berusaha, maka peranan atau emansipasi wanita untuk memiliki harkat dan martabat dengan pria terus meningkat, sehingga pada mulanya sebagai ibu rumah tangga, mulai berubah dan turut secara langsung serta membantu mencukupi kebutuhan hidup keluarga.

Peningkatan produktivitas tenaga kerja wanita tani memiliki peran dan potensi yang strategis dalam mendukung peningkatan maupun perolehan pendapatan rumah tangga pertanian di perdesaan. Dengan berbagai masalah dan kendala dihadapi, baik secara internal maupun eksternal, itu semua merupakan tantangan yang perlu diatasi melalui berbagai cara, seperti: perlindungan terhadap tenaga kerja wanita, peningkatan efektivitas bimbingan penyuluhan dan pelatihan, perbaikan upah tenaga kerja, fasilitas, dan kesempatan kerja. Peluangpeluang tersebut dapat merupakan insentif dan keberpihakan kepada wanita tani. Dimana informasi ini juga sebagai umpan balik (masukan) bagi perencana, penyusun, dan pengambil kebijakan.

Petani wanita perdesaan sudah cukup lama dikenal memiliki peran penting sebagai salah satu tonggak penghasil pangan. Begitu pentingnya peran wanita sehingga tidak ada satu benih pun yang jatuh ke bumi tanpa 
sentuhan tangan wanita, petani wanita memiliki peran yang tidak di ragukan lagi. Mereka terlibat dalam semua tahap kegiatan, mulai dari pengolahan tanah, sampai dengan pemasaran hasil, khususnya pada kegiatan penyiangan, panen, pasca panen, dan pemasarannya.

Mendasarkan latar belakang yang telah disampaikan maka dikemukakan masalah penelitian terkait rumah tangga miskin, upaya wanita petani dalam pengentasan kemiskinan dan kendala yang di hadapi wanita petani dalam pengentasan kemiskinan. Studi dilakukan di perdesaan Jirak menyebutkan tekanan ekonomi memaksa seorang wanita yang berstatus sebagai ibu rumah tangga harus bekerja sebagai wanita petani demi kelangsungan hidup. Pada kondisi terhimpit kemiskinan, tugas utama wanita seharusnya bukan sebagai pencari nafkah, namun karena permasalahan tekanan hidup, daerah yang jauh dari perkotaan dan kondisi yang serba kurang dalam kehidupan rumah tangga yang berada di dusun pedalaman memaksa perempuan mencari kesempatan memperoleh pendapatan guna pemenuhan kebutuhan rumah tangga. Sumbangan pendapatan wanita petani sangat membantu bagi rumah tangga miskin dalam meringankan beban rumah tangga.

Melihat kondisi dusun Jirak yang jauh dari perkotaan juga membuat akses wanita petani tidak dapat bekerja di bidang lain. Selain menjadi petani, wanita petani setiap hari pukul tiga subuh ataupun pukul empat subuh sudah harus berangkat ke hutan untuk bertani. Mulai pada saat pagi sudah harus pulang untuk mengurus rumah dan mengurus anak untuk sekolah. Hal ini menjadi dilema akan wanita petani yang harus bisa mengerjakan semua dalam hal mengurus rumah tangga, anak dan mencari nafkah. Jika kebutuhan ekonomi hanya di cari oleh kepala rumah tangga, maka hal tersebut belum mampu mencukupi kebutuhan keluarga, sehingga peran istri bekerja sangat membantu. Selain itu, masih kurang dan terbatasanya akses ke kota, pendidikan yang kurang baik dan pernikahan dini juga diduga menjadi penyebab kemiskinan. Sehingga saat ini masih banyak penduduk dalam katagori sejahtera 1 di dusun Jirak.

Penelitian ini diharapkan dapat melihat bagaimana seorang wanita petani bekerja, apa yang dikerjakan dalam memperoleh penghasilan, bagaimana wanita petani membagi waktu dalam mengerjakan segalanya di dalam rumah tangga. Penelitian ini diharapkan juga dapat membantu pemerintah dalam mengambil kebijakan khususnya bagi para wanita petani dalam meningkatkan ekonomi rumah tangga dan dapat bekerja secara efisien sehingga tidak harus berangkat ke hutan dari subuh dan meninggalkan rumah mereka sementara anak-anak mereka menunggu sang ibu untuk mempersiapkan semuanya.

\section{METODE PENELITIAN}

Proses penelitian ini akan menghabiskan waktu satu tahun. Penelitian ini dilaksanakan dengan datang langsung ke Dusun Jirak Desa Karya Bhakti Kecamatan Sungai Betung Kabupaten Bengkayang Kalimantan Barat. Secara langsung berinteraksi serta untuk mendapatkan data yang dibutuhkan. Menggunakan beberapa cara yaitu observasi atau pengamatan secara langsung pada wanita petani dalam aktifitas yang dilakukan dari subuh, pagi hingga sore hari. Hal ini guna mendapatkan data yang lebih akurat sehingga pengumpulan data dengan terjun langsung ke lapangan untuk mengamati secara langsung pada obyek yang diteliti. Observasi juga merupakan kegiatan keseharian manusia dengan menggunakan pancaindra (Bungin, 2007). Observasi dilakukan berkaitan dengan pengumpulan bukti dalam mendukung hasil penelitian. Obyek observasi yaitu peran wanita petani berlokasi di Dusun Jirak pedalaman.

Kelompok diskusi terarah atau dikenal sebagai Focus Group Discussion (FGD) dilakukan dengan mengumpulkan para wanita petani dan membentuk Focus Group Discussion. Diskusi kelompok yang digunakan dapat memperoleh fakta dan tanpa mematahkan pendapat dari kondisi yang dialami oleh para kelompok diskusi. Dalam melakukan kegiatan Focus Group Discussion, 
para wanita petani sudah menyelesaikan kegiatannya di kebun/hutan dan di rumah yaitu pada siang hari dan pada hari tertentu yang sudah disepakati bersama.

Menurut Zainuddin

rancangan penelitian dapat diartikan, rencana tentang bagaimana cara mengumpulkan, menyajikan dan menganalisis data untuk memberikan arti terhadap data tersebut secara efisien dan efekstif. Rancangan penelitian meliputi tahapan penentuan alat (instrument), pengambilan data yang digunakan, cara pengumpulan, pengaturan dan analisis data yang akan digunakan pemberian kesimpulan atas hasil analisis yang telah dilakukan.

Survey pendahuluan dalam
menginterprestasikan ketertarikan untuk melakukan penelitian dalam mengentaskan kemiskinan pada peran wanita rumah tangga petani yang awal mulanya berasal dari jurnal-jurnal penelitian baik yang berkaitan dengan ilmu ekonomi pembangunan maupun berkaitan dengan peran wanita dalam meningkatkan ekonomi rumah tangga petani.

Informasi yang digunakan tidak hanya disebutkan sebelumnya namun peneliti mengembangkan pencarian informasi melalui pendapat para ahli dan dokumen pemerintah. Hal Tersebut mendukung pemahaman peneliti dan tertarik untuk melanjutkan dalam bentuk penelitian yang dapat memberikan informasi tentang peran wanita petani yang dapat di jadikan sebagai obyek penelitian dan peneliti terfokus pada peran wanita petani yang akan dijadikan obyek penelitian.

Dokumentasi yang dilakukan untuk pengumpulan data bersumber dari beberapa foto yang diambil dari lapangan. Arikunto (2006) menunjukkan bahwa catatan, transkip, buku, surat kabar, majalah, prasasti, notulen rapat, agenda dan sebagainya.

\section{HASIL DAN PEMBAHASAN}

Wanita dalam keluarga mempunyai kedudukan antara lain sebagai teman hidup, kekasih, ibu dalam arti tidak ada diskriminasi antara anggota keluarga. Wanita sebagai ibu berhak ikut menentukan dan berhak ikut melakukan kekuasaan bagi keselamatan dan kebahagiaan baik dalam bidang imaterial maupun material seluruh anggota. Menurut pengamatan kondisi wanita di dusun Jirak ternyata menunjukan peran istri petani dan suami saling melengkapi dalam memenuhi kebutuhan ekonomi rumah tangganya. Demikian pula dalam kehidupan rumah tangga petani pada umumnya menunjukkan masih banyak yang tergolong miskin. Untuk itu dalam memenuhi kebutuhan ekonomi rumah tangganya, semua anggota rumah tangga harus bekerja termasuk istri petani.

Wanita petani di Dusun Jirak berperan dalam menentukan ekonomi keluarga agar keadaan keluarga merasa sejahtera dan berkecukupan. Peran wanita petani dalam meningkatkan ekonomi keluarga dan mengentaskan kemiskinan di Dusun Jirak ditunjukkan pada Tabel 1.

Tabel 1 memperlihatkan bagaimana pendapatan para wanita petani dalam kegiatannya bekerja menjadi petani penyadap karet. Selain itu mereka melakukan kegiatan berkebun, namun hasilnya seperti sayuran masih dikonsumsi untuk keluarga dalam memenuhi kebutuhan makan sehari- hari.

Terdapat beberapa wanita petani yang memiliki pendapatan perhari, perminggu hingga perbulan dan ada juga yang tidak menentu. Hal tersebut terjadi karena kegiatan menyadap karet terkadang tidak dilakukan pada saat cuaca yang tidak baik. Sehingga faktor cuaca juga berpengaruh terhadap perolehan pendapatan wanita petani. Selain itu, pendapatan per hari, per minggu dan perbulan yang berbeda-beda dikarenakan kebutuhan hidup yang mereka perlukan setiap harinya atau penjualan hasil menyadap karet.

Penjualan hasil menyadap karet dapat langsung dilakukan pada hari itu juga, Namun terkadang sebagian wanita petani juga menggumpulkan hingga banyak dan memenuhi kriteria pembeli. Terdapat jenisjenis karet yang dinilai baik dan dibeli dengan harga cukup tinggi. Faktor yang ketiga yang mempengaruhi pendapatan tidak merata yaitu 
Tabel 1. Pendapatan Wanita Petani Dusun Jirak

\begin{tabular}{|c|c|c|c|}
\hline $\begin{array}{l}\text { Nama Wanita } \\
\text { Petani }\end{array}$ & Per/hari & Per/minggu & Per/bulan \\
\hline Wanita petani 1 & - & - & Rp. $200.00 C$ \\
\hline Wanita petani 2 & Rp. 30.000 & Rp. 200.000 & Rp. $700.00 \mathrm{C}$ \\
\hline Wanita petani 3 & - & Rp. 200.000 & Rp. 500.00C \\
\hline Wanita petani 4 & Rp. 50.000 & Rp. 70.000 & - \\
\hline Wanita petani 5 & - & - & Rp. 500.00C \\
\hline Wanita petani 6 & Rp. 30.000 & Rp. 200.000 & Rp. 900.00C \\
\hline Wanita petani 7 & Rp. 15.000 & Rp. 35.000 & Rp. $800.00 C$ \\
\hline Wanita petani 8 & 1 & - & Rp. 500.00C \\
\hline Wanita petani 9 & Rp. 50.000 & Rp. 100.000 & Rp. 600.00C \\
\hline Wanita petani 10 & Rp. 10.000 & Rp. 50.000 & Rp. 500.00C \\
\hline
\end{tabular}

Sumber: hasil data pada kegiatan Focus Group Discussion (FGD)

kurang baiknya akses jalan untuk ke kota guna menjual hasil- menyadap karet dan kebun tersebut dan sebagian besar dari keluarga wanita petani tidak memiliki kendaraan pribadi hal ini dari petani pada pembeli di sekitar desa yang membeli dengan cukup murah.

Dengan melihat betapa besarnya perjuangan wanita petani di Dusun Jirak pedalaman dalam meningkatkan ekonomi rumah tangga mereka rela bekerja dari subuh hingga sore demi keluarga agar terbebas dari kemiskinan, anak-anak bisa sekolah dan kebutuhan untuk makan setiap hari tepenuhi. Tabel 1 menunjukan pendapatan wanita petani enam sebesar Rp. 900.000, ketujuh Rp. 800.000 dan kedua sebesar Rp. 700.000 memiliki jumlah pendapatan cukup tinggi dibandingkan dengan pendapatan wanita tani lainnnya hal ini dikarenakan sebagian wanita petani ini memiliki kendaraan yang dapat mereka gunakan untuk mejual hasil tani ke kota agar memperoleh pendapatan yang cukup tinggi dan lebih sering menyimpan karet yang jika sudah banyak baru di jual ke kota.
Kegiatan Focus Group Discussion (FGD) dilakukan guna mendapatkan data yang lebih akurat dalam mengetahui peran wanita petani di dusun Jirak dalam meningkatkan ekonomi rumah tangga/keluarga. Semangat yang sangat besar bisa dirasakan peneliti melihat para wanita petani ini ingin berjuang hidup demi adanya ekonomi yang baik dan semua tercukupi. Peran wanita petani bekerja membantu suami di dusun Jirak sangat berperan penting dalam meningkatkan ekonomi keluarga.

Keterlibatan wanita dalam kegiatan pertanian mungkin sudah dimulai sejak aktifitas bertani muncul di bumi. Perempuan tidak saja menjadi bagian terbesar dari tenaga kerja di sektor pertanian, tetapi juga memiliki pengetahuan dan keterampilan memilih benih padi yang baik dan menyimpannya untuk ditanam pada musim tanam berikutnya. wanita juga mampu memilih lahan yang cocok untuk budidaya pertanian. Mereka juga mampu memilih tanaman yang cocok untuk pengobatan.

Kemampuan tersebut dengan dipelajari para wanita untuk kebutuhan bertahan hidup keluarganya. Peran wanita 
dalam pertanian tidak hanya penting di sektor budidaya tanaman, tetapi wanita juga terlibat dalam produksi ternak dan perikanan, pengumpulan bahan makanan, pelaku pasca panen, pengolahan makanan, dan pedagang hasil pertanian.

Para wanita petani di dusun Jirak berkumpul memberikan informasi mengenai kehidupan, motivasi, berbagi mengenai informasi terkait data yang diperlukan oleh peneliti. Masukan bagi pemerintah setempat agar lebih memperhatikan mereka yang berada di pedalaman.

Agar dapat menyelesaikan permasalahan yang ada di dusun jirak, dengan memberikan pelatihan kepada para kaum wanita petani, membentuk kelompok wanita tani di tiap dusun dan kegiatan yang lebih efektif dalam memberikan bantuan.

Peran wanita dalam keluarga merupakan peranan yang dilaksanakan perempuan karena menduduki posisi dalam masyarakat. Peran wanita dalam keluarga dengan melakukan pekerjaan rumah tangga seperti memasak, mengassuh anak, melayani suami, merupakan suatu kegiatan produktif yang secara tidak langsung menambah pendapatan kelaurga. menonjolkan diri atau mengklaim bahwa mereka menjadi penyangga utama ekonomi keluarga.

\section{KESIMPULAN}

Kesimpulan dari penelitian ini menyatakan bahwa wanita petani di dusun Jirak memiliki peranan sangat penting dalam menunjang kehidupan sehari-hari. Meskipun pendapatan yang mereka peroleh tidak banyak, akan tetapi mampu memenuhi kebutuhan keluarga untuk membantu suami mencari nafkah. Perbedaan pendapatan wanita petani di dusun Jirak diantaranya ditentukan oleh faktor kualitas karet serta kemampuan akses dalam menjual karet ke kota. Kepada pemerintah diharapkan lebih memperhatikan kesejahteraan masyarakat miskin terutama yang berada di daerah 3T.

\section{REFERENSI}

Dewi, Ni Luh Ayu Fitri Meira. 2011. Pengaruh Usaha Kelompok Wanita Tani "Mekar Usaha” Terhadap Pendapatan Keluarga Di Banjar Dinas Saren

Soekanto, S. 2009. Sosiologi Suatu Pengantar, Edisi Baru, Rajawali Pers. Jakarta.

Staggenborg, S. 2003. Gender, Keluarga, \& Gerakan-Gerakan Sosial. Mediator. Jakarta

Tim Pena. 2000. Kamus Kauh, Desa Budakeling, Kecamatan file:///C:/Users/user/Downloads/481871-1-SM.pdf.

Purwanto. Model Pengurangan Kemiskinan Upaya Melalui Penguatan Ketahanan Pangan.

Wibowo, B Junianto. 2000. Profil Wanita Pedagang Kecil di Tinjau dari Aspek Ekonomi (Studi Kasus pada Tiga Pasar Tradisional di Kota Semarang, Yaitu Pasar Mangkang). Seri Kajian Ilmiah Vol. 11 no. Lestari dalam Haryanto, Sugeng. 2016. Kontribusi Wanita dalam Agribisnis Gula Semut di Kabupaten Blitar Provinsi Jawa Timur. Jurnal Penelitian Ilmu-Ilmu sosial Vol. 9 No. 1 Februari

Marium, N, Badrun. 2004. Kontribusi Perempuan pada Peningkatan PendapatanRumah Tangga Miskin: Studi kasus di 4 Kabupaten/ Kota. Warta Demografi Tahun 34 No 3.

Ahmadi, 2005, Memahami Metodologi Penelitian Kualitatif, Univ. Negeri Malang.

Arikunto S, 2006. Prosedur Penelitian Suatu Pendekatan Praktik, Ed Revisi VI, Penerbit PT Rineka Cipta, Jakarta.

Creswell, J.W, 2007, Qualitative Inquiry and Research Desing Choosing Among Five Approaces (3rd ed). Thousand Oaks, CA: Sage.

Chen, M. J, Vanek, dan J., Hentz. 2006. Informality, Gender and Poverty. Economic and Political Weekly. 
Levinson dalam Soekanto, 2012. Sosiologi Suatu Pengantar, Edisi Baru, Rajawali Pers. Jakarta.

Nugroho, Riant. 2008. Gender dan Adminstras Publik. Pustaka Pelajar.Yogyakarta 2015.

Zainuddin, Muhamad, 1998, Metodologi Penelitian, Surabaya: Ilmu Manajemen Program Pascasarjana Universitas Airlangga.

Marium, N, Badrun. 2004. Kontribusi Perempuan pada Peningkatan PendapatanRumah Tangga Miskin: Studi kasus di 4 Kabupaten/ Kota. Warta Demografi Tahun 34 No 3.

Suryana, A. (2000). Peran sektor pertanian dalam memenuhi kecukupan pangan Nasional. Dalam Prosiding Kerja Sama IPPTP Denpasar dengan Universitas Udayana, Denpasar.

Wibowo, B Junianto. 2000. Profil Wanita Pedagang Kecil di Tinjau dari Aspek Ekonomi ( Studi Kasus pada Tiga Pasar Tradisional di Kota Semarang, Yaitu Pasar Mangkang). Seri Kajian Ilmiah Vol. 11 no.

Davran, Müge. 2004. Participation of Women Farmer and Women Agricultural Engineer to Water Management in Turkey From the Gender Point of View: Threads and Opportunities. http://www.fao.org. 